\title{
APLIKASI PENGENALAN KOLEKSI MUSEUM LAMPUNG BERBASIS ANDROID
}

\author{
${ }^{1}$ Shafina Azzahra, ${ }^{2}$ Febi Eka Febriansyah \\ ${ }^{1,2}$ Jurusan Ilmu Komputer FMIPA Universitas Lampung \\ ${ }^{1}$ shafinaazzahra78@gmail.com, ${ }^{2}$ febief@gmail.com
}

\begin{abstract}
Lampung Museum is the largest museum in Lampung Province, in the formation of the history of Lampung Province so that its existence needs to be preserved. currently information technology is needed in every field. the number of visitors to the Lampung Museum 2011-2017 reached 70,000 visitors. In this study the application of the Introduction to Lampung Museum Collection based on Android can increase the interest of the Lampung community as well as foreign tourists to visit and see the Museum collection, the application is equipped with a barcode scan facility that allows visitors to search collection information. The results of the study have been successfully built an "Introduction to Museum Lampung Collection Application" which has a museum collection menu, museum history, museum info, QR code scans, navigation, assistance, and about. The results of this study are: (1) functional testing with the Black Box Testing method obtain results as expected, (2) assessment using a questionnaire with the calculation of Likert Scale method, obtain a value of $88.2 \%$ in user friendly variables, and $85.06 \%$ in interactive variables, values included in the category "Very Good". it can be concluded that this application runs very well and can be used by the community.
\end{abstract}

Keywords: Collection of Lampung Museum, QR Code, Moving Application, Android, Online Museum

\section{Pendahuluan}

Museum merupakan sebuah lembaga yang berfungsi sebagai tempat penyimpanan, perawatan, pengamanan dan pemanfaatan benda-benda seni budaya manusia serta alam beserta lingkungannya guna menunjang upaya perlindungan dan pelestarian kekayaan budaya bangsa. Peran museum yaitu sebagai lembaga pendidikan non-formal, di mana lebih menonjolkan aspek edukasi dibanding aspek rekreasi. Selain itu museum juga merupakan salah satu lembaga pelestarian kebudayaan Bangsa yang berupa fisik seperti artefak, fosil, maupun yang berupa nonfisik seperti adat, tradisi, dan norma.

Museum Negeri Provinsi Lampung "Ruwa Jurai" merupakan museum yang pertama dan terbesar di Provinsi Lampung. Museum Lampung berfungsi sebagai sarana sumber pembelajaran dan pengetahuan tentang sejarah Provinsi Lampung. Berdasarkan data pengunjung Museum Lampung dari tahun 2011-2017 jumlah pengunjung dalam 7 tahun terakhir cenderung stabil di angka 70.000. Untuk meningkatkan minat masyarakat agar berkunjung ke museum Lampung dibutuhkan sebuah sistem yang dapat mengumpulkan data koleksi museum tersebut sehingga memudahkan calon pengunjung atau masyarakat Lampung untuk memperoleh informasi tentang sejarah kebudayaaan Lampung dengan memberikan informasi tentang koleksi yang ada pada Museum Lampung.

Sebuah penelitian mengenai rancang bangun pemandu virtual berbasis mobile untuk Museum Lampung menggunakan Augmented Reality telah dilakukan pada tahun 2014. Namun aplikasi 
mobile ini menggunakan webcam pc sehingga dapat dijalankan di sistem operasi mobile phone dengan cara menginstall aplikasi Popcode terlebih dahulu pada handphone pengguna. [1].

Pada penelitian ini, peneliti ingin membangun aplikasi Dengan memanfaatkan teknologi mobile sehingga User akan mendapatkan informasi tentang koleksi yang ada pada museum Lampung, selain itu user juga dapat melihat detail koleksi berupa gambar dan deskripsi dari koleksi yang ada. Aplikasi yang akan dibangun juga dilengkapi fasilitas scan Barcode, setiap koleksi di Museum Lampung akan dilengkapi Barcode, Barcode tersebut dapat di-scan dan aplikasi akan memberikan informasi lengkap terkait koleksi museum tersebut.

\section{Metode Pengembangan Aplikasi}

Tahap pengembangan aplikasi dengan metode Waterfall adalah sebagai berikut:

1. Analisa kebutuhan sistem Analisa kebutuhan sistem atau aplikasi merupakan tahapan pertama yang menjadi dasar proses pembuatan sistem. Pada tahap ini dilakukan pencarian dan pengumpulan semua data yang diperlukan untuk menunjang kelengkapan sistem atau aplikasi, kemudian mendefinisikan semua kebutuhan yang dipenuhi dalam perangkat lunak atau aplikasi yang dibuat.

2. Pengujian aplikasi

Pengujian aplikasi dilakukan untuk memastikan bahwa sistem yang dibuat telah sesuai dengan desain dan semua fungsi dapat dipergunakan dengan baik tanpa ada kesalahan sesuai dengan kebutuhan pengguna. Pengujian aplikasi ini menggunakan metode Black Box Testing.

3. Penerapan

Pada tahapan ini, aplikasi sudah siap untuk diterapkan pada perangkat mobile dan siap digunakan sesuai dengan tujuan dibuatnya aplikasi ini. Perawatan, perbaikan dan pengembangan aplikasi dilakukan untuk menjaga kualitas dan kestabilan aplikasi.

\section{Pembahasan}

1. Analisis Kebutuhan Sistem

Kebutuhan fungsional untuk membangun aplikasi ini yaitu data koleksi museum yang dipamerkan di Museum Lampung.

\section{Usecase Diagram}

Usecase diagram digunakan untuk menggambarkan sistem dari sudut pandang pengguna sistem tersebut, sehingga pembuatan usecase diagram ini lebih dititikberatkan pada fungsionalitas yang ada pada sistem pada sistem ini pengguna dapat melakukan 7 interaksi. Usecase diagram aplikasi Pengenalan Koleksi Museum Lampung dapat dilihat pada Gambar 1 


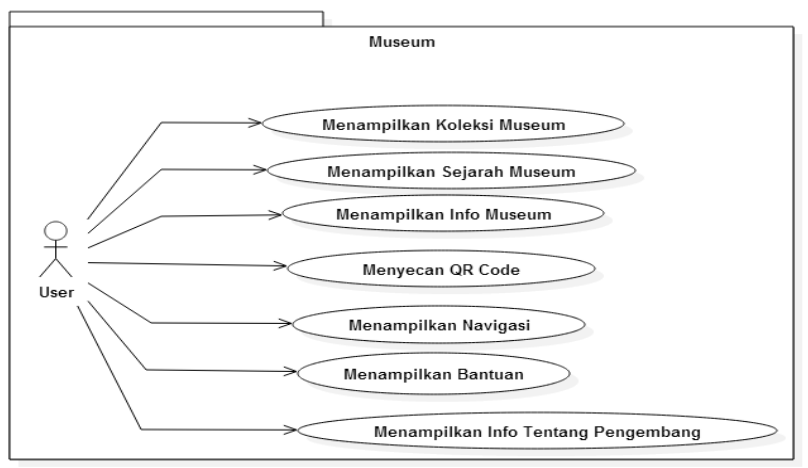

Gambar 1 Usecase Diagram

3. Tampilan Aplikasi

Tampilan aplikasi Pengenalan Koleksi Museum Lampung adalah sebagai berikut :

1. Layout Halaman Utama

Pada menu utama terdapat gambar yang dapat tampil dan berubah secara otomatis, yang menampilkan gambar suasana museum Lampung. Setelah itu terdapat 7 menu yaitu koleksi museum, sejarah museum, info museum, scan QR code, navigasi, bantuan, dan tentang developer. Halaman utama dapat dilihat pada Gambar 2.

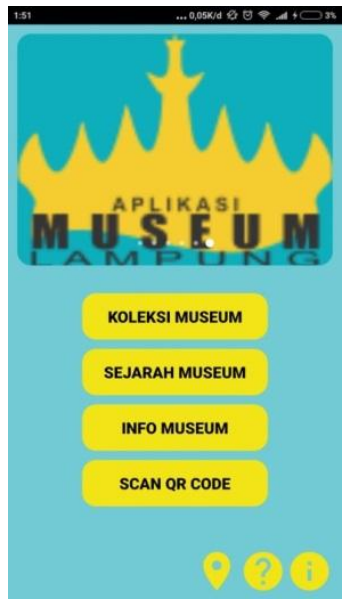

Gambar 2 Layout Halaman Utama

\section{Layout Menu Koleksi Museum}

Menu menu koleksi museum berisi daftar koleksi yang ada pada museum Lampung. Pengguna dapat memilih lantai untuk melihat kategori apa saja yang di pamerkan di lantai 2 dan lantai 1. Layout menu koleksi museum dapat dilihat pada Gambar 3. 
C2019 Ilmu Komputer Unila Publishing Network all right reserve

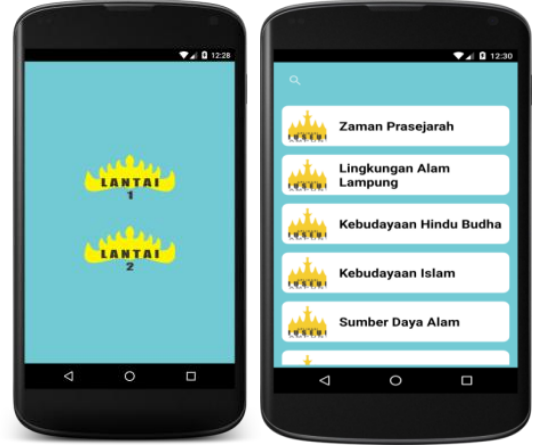

(a) Layout Lantai (b) Layout Kategori Lantai 1

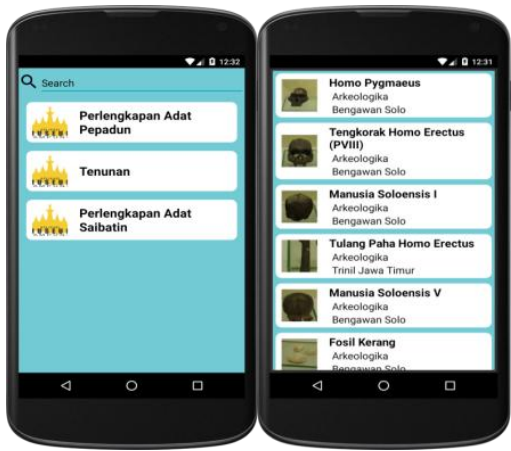

(c) Layout Kategori Lantai 2 (d) Koleksi Lantai1

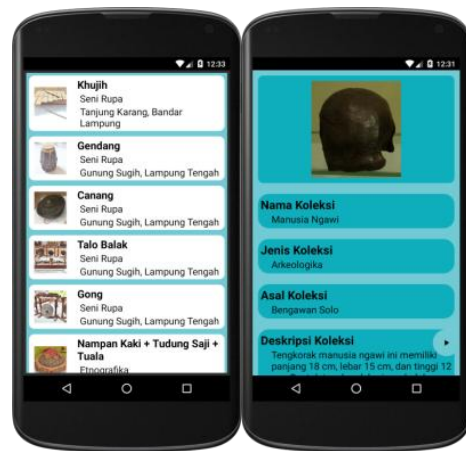

(e) Koleksi Lantai 2 (f) Detail Koleksi

Gambar 3 Layout Menu Koleksi Museum

3. Layout Menu Sejarah Museum

Pada menu ini aplikasi akan menampilkan sejarah dari museum Lampung. Layout menu sejarah museum dapat dilihat pada Gambar 4.

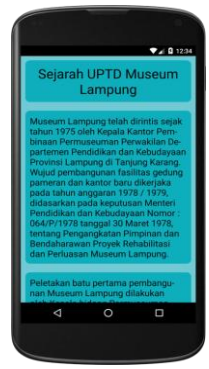

Gambar 4 Layout Menu Sejarah Museum 


\section{Layout Menu Info Museum}

Pada menu ini aplikasi terdapat gambar yang ditampilkan serta dapat berganti secara otomatis, kemudian menu ini menampilkan info museum yang meliputi jam operasional museum, harga tiket masuk, contact person museum dan email museum Lampung. Layout menu info museum dapat dilihat pada Gambar 5.

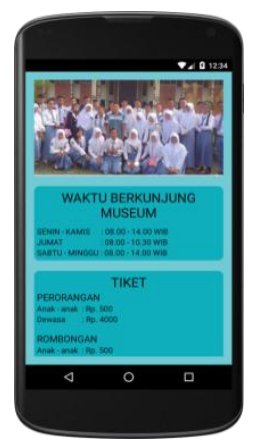

Gambar 5 Layout Menu Info Museum

\section{Layout Menu Scan QR Code}

Pada menu scan QR Code ini akan menampilkan fungsi kamera kemudian pengguna mengarahkan kamera ke barcode yang telah disediakan. Setelah itu sistem akan mencocokkan barcode dengan database kemudian tampil detail koleksi sesuai dengan barcode yang telah di scan sebelumnya. Layout menu scan QR Code dapat dilihat pada Gambar 6.
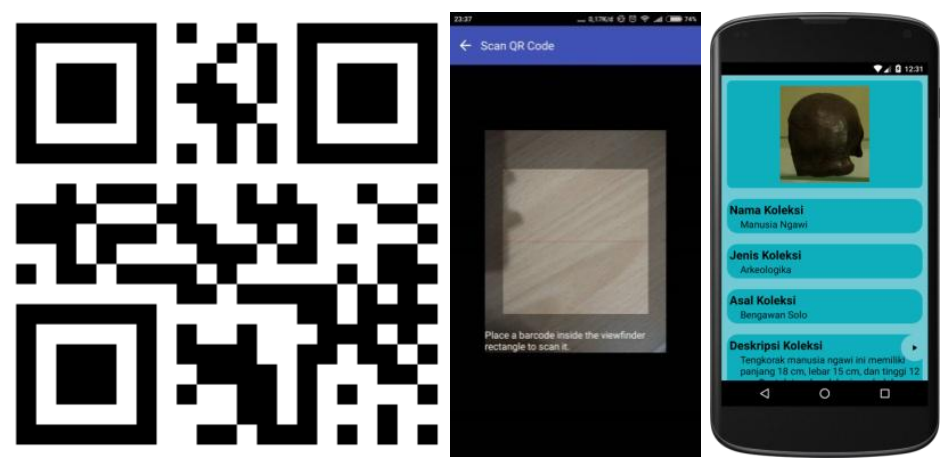

(a) Barcode (b) Scan QR Code (c) Hasil Scan QR Code Gambar 6 Layout Menu Scan QR Code

\section{Layout Menu Navigasi}

Pada menu navigasi ini akan menampilkan layout peta yang dapat membantu pengguna yang belum pernah mengunjungi museum Lampung untuk mengarahkan ke museum Lampung. Layout menu navigasi dapat dilihat pada Gambar 7. 


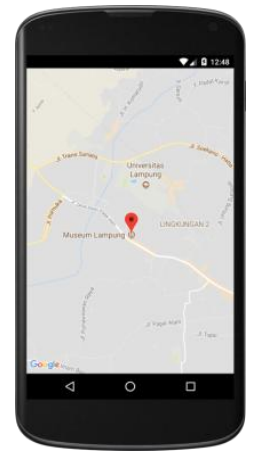

\section{Layout Menu Bantuan}

\section{Gambar 7 Layout Menu Navigasi}

Pada menu bantuan ini aplikasi akan menampilkan layout petunjuk cara penggunaan aplikasi pengenalan koleksi museum Lampung, dengan cara menjelaskan isi serta fungsi dari semua menu yang ada pada aplikasi pengenalan koleksi museum Lampung. Layout menu bantuan dapat dilihat pada Gambar 8.

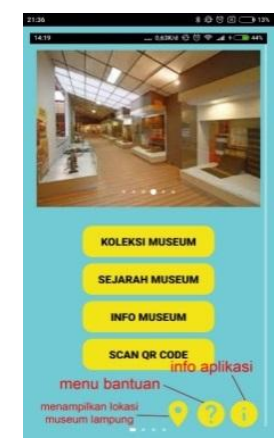

Gambar 8 Layout Menu Bantuan

\section{Layout Menu Tentang Developer}

Pada menu ini aplikasi akan menampilkan informasi mengenai aplikasi pengenalan koleksi museum Lampung. Pada layout menu tentang terdapat tulisan yang menginformasikan versi dari aplikasi pengenalan koleksi museum Lampung dan informasi developer. Layout menu tentang developer dapat dilihat pada Gambar 9.

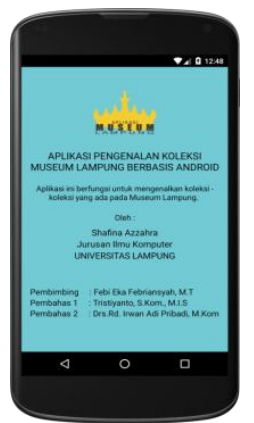

Gambar 9 Layout Menu Tentang Developer 


\section{Hasil Pengujian}

\section{Pengujian Fungsional}

Pengujian fungsional dilakukan untuk menemukan apakah ada kesalahan-kesalahan pada aplikasi yang telah dibangun, beberapa kesalahan yang dapat diidentifikasi: fungsi tidak benar atau hilang, kesalahan interface, kesalahan pada struktur data Metode yang digunakan dalam pengujian fungsional ini adalah metode equivalence partitioning. Pengujian dilakukan dengan membagi kelas uji yaitu pengujian versi Android, ukuran dan densitas layar, pengujian user interface dan pengujian fungsi dan menu aplikasi. Pengujian ini membuktikan bahwa aplikasi yang telah dibuat telah berjalan sesuai dengan yang diharapkan. Semua fungsi dari menu telah berjalan sesuai dengan yang diharapkan [3].

\section{Pengujian Non Fungsional}

Pengujian non fungsional didasarkan pada pengujian aplikasi dari atribut non fungsional, pengujian non fungsional melibatkan pengujian perangkat lunak dan persyaratan yang non fungsional seperti, tampilan (user interface), kinerja aplikasi dan mudah digunakan (user friendly).

Pengujian non fungsional melibatkan 50 (lima puluh) responden untuk mendapatkan penilaian langsung terhadap sistem yang dihasilkan. Pemilihan responden didasarkan pada pengambilan sampel acak.

Berdasarkan index yang didapat rata-rata nilai persentase sebesar $88.2 \%$ untuk variabel user friendly dan rata-rata nilai persentase sebesar 85.06 untuk variabel interaktif. Maka dapat disimpulkan sebagai berikut :

1. Kesesuaian warna background, icon dan teks pada aplikasi sudah cukup baik.

2. Kualitas gambar yang disediaka aplikasi sudah cukup baik.

3. Aplikasi dapat membantu masyarakat untuk mencari informasi tentang koleksi yang dipamerkan di museum Lampung.

4. Aplikasi menampilkan hasil scan barcode koleksi museum dengan baik.

5. Aplikasi menampilkan informasi koleksi yang dipilih oleh pengguna dengan baik.

6. Fungsi-fungsi yang ada pada aplikasi sudah berjalan dengan baik.

\section{Kesimpulan dan Saran}

\section{Kesimpulan}

Berdasarkan penelitian yang telah dilakukan dapat disimpulkan beberapa hal sebagai berikut :

1. Telah berhasil dibangun aplikasi layanan pengenalan koleksi museum Lampung untuk membantu masyarakat ataupun wisatawan untuk mencari informasi koleksi yang dipamerkan di museum Lampung.

2. Aplikasi ini menerapkan sistem barcode untuk mempermudah masyarakat atau wisatawan mencari deskripsi dari koleksi yang ada di museum.

3. Dari pengujian ukuran layar yang dilakukan pada Android dengan ukuran layar 4 inch, 4.5 inch, 4.7 inch, 5 inch dan 5.5 inch berdasarkan test case yang diberikan, sistem ini dapat berjalan dengan baik pada Android dengan layar yang diujikan.

4. Dari pengujian user interface yang dilakukan, berdasarkan test case yang diberikan, dapat disimpulkan bahwa tampilan yang disediakan untuk pengguna (user) dapat berjalan dengan baik dan sesuai yang diharapkan.

5. Dari pengujian fungsi dari menu aplikasi yang dilakukan, berdasarkan test case yang diberikan, dapat disimpulkan bahwa fungsi dari masing-masing menu aplikasi dapat berjalan dengan baik sesuai dengan yang diberikan 
6. Berdasarkan hasil kuisioner yang telah dibagikan kepada 50 mahasiswa, dari hasil perhitungan kuisioner tersebut dapat disimpulkan bahwa aplikasi ini mendapatkan rata-rata persentase penilaian sebesar $88.2 \%$ untuk variabel user friendly dan rata-rata persentase sebesar $85.06 \%$ untuk variabel interaktif. Bedasarkan persentase tersebut, aplikasi ini termasuk dalam kategori "Sangat Baik".

\section{Saran}

Berdasarkan penelitian yang dilakukan maka diperoleh beberapa saran untuk pengembangan aplikasi ini lebih lanjut sebagai berikut :

1. Aplikasi dapat dikembangkan dengan menambahkan Bahasa asing.

2. Aplikasi dapat dikembangkan dengan menambahkan fitur video interaktif ataupun teknologi Augmented Reality (AR).

3. Aplikasi ini nantinya dapat dikembangkan sehingga dapat kompetibel pada platform selain Android. Seperti IOS, Blackberry OS ataupun Windows Phone.

\section{Referensi}

[1] Deasy, K. A. 2014. Rancang Bangun Pemandu Virtual Berbasis Mobile Untuk Museum Lampung Menggunakan Augmented Reality.

[2] Fowler, Martin. 2004. UML Distilled Panduan Singkat Bahasa pemodelan Objek Standar, Edisi 3. Andi Publishing, Yogyakarta.

[3] Pressman, Roger S. 2001. Software Engineering A Practitioner's Approach FifthEdition. McGraw-Hill Companies, Inc, New York 